\title{
Effects of low doses of dexamethasone on productive traits and meat quality of veal calves
}

\author{
M. Tarantola ${ }^{1}$, A. Schiavone ${ }^{1}$, G. Preziuso ${ }^{2}$, C. Russo ${ }^{2}$, B. Biolatti ${ }^{3}$ and D. Bergero ${ }^{1}$ \\ ${ }^{1}$ Dipartimento di Produzioni Animali, Epidemiologia ed Ecologia, Università di Torino, Via Leonardo da Vinci 44, 10095 \\ Grugliasco (TO), Italy \\ ${ }^{2}$ Dipartimento di Produzioni Animali, Università di Pisa, Viale delle Piagge, 2, 56124 Pisa, Italy \\ ${ }^{3}$ Dipartimento di Patologia animale, Università di Torino, Via Leonardo da Vinci 44, 10095 Grugliasco (TO), Italy \\ † E-mail : martina.tarantola@unito.it
}

\begin{abstract}
An experimental administration of dexamethasone was carried out on 15 veal calves in order to assess the rôle of low doses of exogenous glucocorticoids on productive traits and meat quality. Three groups, of five veal calves each, were formed: one group received oral dexamethasone ( $0.4 \mathrm{mg}$ per calf per day for 25 days), another intramuscular (i. m.) dexamethasone (2 mg at days 14 and 21), and the third was the control. Calves were slaughtered at 165 days of age (day 31).

Food conversion ratio (FCR), hot dressing percentage (HDP), chilled dressing percentage (CDP) and shrinkage were determined. From all carcasses, samples of $\mathrm{m}$. longissimus thoracis (between the 8th and 10th rib) were taken in order to evaluate the chemical composition and some organoleptic characteristics: meat colour, waterholding capacity and tenderness.

The animals treated with oral dexamethasone showed the lowest daily weight gain $(\mathrm{P}<0.05)$ and the poorest FCR $(\mathrm{P}<0 \cdot 05)$. Hot dressing percentage, cold dressing percentage and shrinkage were not affected by the oral treatment. The i. m. injections of dexamethasone did not influence the overall performance.

Muscle chemical composition and $\mathrm{pH}$ were not affected by the treatments; the meat of calves treated with oral dexamethasone was significantly lighter $(\mathrm{P}<0.05)$ and tended to be paler, while i.m. treatment induced intermediate characteristics. The shear force of the meat was rather low. Shear force of cooked meat from animals treated with dexamethasone (both oral and i.m.) was significantly lower than the control $(P<0.05)$. Treatment with dexamethasone i.m. induced a decrease in water-holding capacity; the oral treatment had no effect on this parameter.
\end{abstract}

Keywords: dexamethasone, meat production, meat quality, veal calves.

\section{Introduction}

Breeding of calves plays a pivotal rôle in bovine meat production in Italy (in fact it supplies around 14\% of the whole production of beef meat (Istat, 2001)). The consumers appreciate calves meat for its pale colour and because it is believed to be more digestible. Mostly Friesian males are used for this breeding and they have to be slaughtered because they exceed the required restocking rate.

This category of meat production is now a major topic of research and discussion by the European
Commission for the directive on welfare minimum standards for the protection of calves.

Glucocorticoids have important functions in gluconeogenesis, glycogen deposition, protein and calcium metabolism, together with antiinflammatory and immunosuppressive activities. Dexamethasone and prednisolone are well-known synthetic glucocorticosteroids.

The administration of these agents is also thought to increase animal weight gain through their positive effects on animal well being and food intake. 
Moreover, synthetic glucocorticoids are included as an ingredient in illegal drug 'cocktails' added to the food presumably because they potentiate the activity of $B$-adrenergic growth promoters and possibly the effects of anabolic steroids (Ungemach, 1997).

It is well known that in some European countries glucorticoids are used illegally in association with anabolic steroids as growth promoters, in veal calves and beef production, in order to improve the quality and quantity of the meat produced (Courtheyn et al., 1993).

In the last 15 years farmers have progressively reduced dosages of these drugs to avoid the penalties due to the preventative action carried out by the public veterinary services.

The aim of this work was to describe productive traits following the administration of low doses of glucocorticoids to veal calves, since a spread of this illegal treatment is highly suspected and in some cases confirmed by the occurrence of anatomopathological findings at the slaughterhouses (Biolatti et al., 1999 and 2002).

\section{Material and methods}

Animals, diet and treatments

The trial was carried out on 15 Italian Friesian veal calves 1 week of age housed in a farm situated in Piemonte (North West Italy). The animals were housed in a 'local traditional way': in individual crates $(0.80 \times 1.80 \mathrm{~m})$ with concrete floor without litter and with lateral partitions with no fences. The calves were tethered.

The animals were offered liquid milk replacer, twice a day (providing per $\mathrm{kg}$ : dry matter (DM) $950 \mathrm{~g}$, crude protein (CP) $230 \mathrm{~g}$, ether extract (EE) $210 \mathrm{~g}$, ash $60 \mathrm{~g}$, cellulose $1 \mathrm{~g}$, retinol $7.5 \mathrm{mg}$, ascorbic acid $50 \mathrm{mg}$, Cu $5 \mathrm{mg}$, cholecalciferol $0.125 \mathrm{mg}$, alphatocopherol $80 \mathrm{mg}$ ) with the amount increased gradually up to 161 per calf per day; after 1 month a quantity of $0.5 \mathrm{~kg}$ of barley straw (per $\mathrm{kg}$ : DM $900 \mathrm{~g}$, CP $20 \mathrm{~g}$, EE $10 \mathrm{~g}$, ash $60 \mathrm{~g}$, crude fibre $410 \mathrm{~g}$ ) was added to the diet according to the indications suggested by the European Commission (1997).

Three groups of five veal calves each were formed. The first group was administered $0.4 \mathrm{mg}$ per calf per day of oral dexamethasone-21-phosphate (D21P) from the 135th to the 159th day of age (days 1 to 25 of the experiment). Animals received a total of $10 \mathrm{mg}$ of $\mathrm{D} 21 \mathrm{P}$ and the withdrawal lasted 6 days. In the second group each animal was administered $2 \mathrm{mg}$ of dexamethasone-21-isonicotinate intramuscular injection (i. m.) twice : at the 148 th and 155th day of age (days 14 and 21 of the experiment), for a total of $4 \mathrm{mg}$ per animal. The withdrawal lasted 10 days. A third group served as control. All calves were slaughtered at the 165th day of age (day 31).

\section{Animal performance}

Food intake was individually measured on a daily basis; individual weight was recorded weekly to estimate the average daily gain and to calculate the food conversion ratio (FCR).

The animals were also weighed immediately prior to the slaughter, then hot carcass weight was recorded to calculate hot dressing percentage (HDP).

After chilling the carcasses for $24 \mathrm{~h}$ in a cool chamber (at $0^{\circ}$ to $4^{\circ} \mathrm{C}$ ), cold carcass weight was recorded to determine chilled dressing percentage (CDP) and shrinkage.

\section{Meat analysis}

From all carcasses, samples of $m$. longissimus thoracis (between the 8th and 10th rib) were taken, vacuum packaged, stored for 6 days at $4^{\circ} \mathrm{C}$ and used for meat analysis. The left side samples were used for chemical analysis while the right side samples for some organoleptic evaluations after opening the vacuum-package (colour, water-holding capacity, shear force).

Chemical composition. The chemical composition was evaluated for DM and ash by oven method, CP by Kjeldhal method and EE using Soxhlet extraction technique (Association of Official Analytical Chemists, 1990). The values were expressed as $\mathrm{g} / \mathrm{kg}$ on fresh-matter basis.

$p H$. Before submitting meat samples to organoleptic evaluation, $\mathrm{pH}$ values were measured, using a Hanna pH 211 pH-meter, provided with a Hanna FC200B electrode and an automatic temperature compensator.

Meat colour. Meat colour was evaluated using a Minolta CR300 colourmeter (Illuminant D 65), calibrated using a standard white tile in the CIEL*a*b* system, which measures the values of coordinates lightness $\left(\mathrm{L}^{*}\right)$, saturation $\left(\mathrm{C}^{*}\right)$ and hue $\left(\mathrm{H}^{*}\right)$ (Renerre, 1982); this was done by taking three readings for each sample consisting of a slice of meat $2.5-\mathrm{cm}$ thick covered with polyethylene film and refrigerated for $45 \mathrm{~min}$ at $4^{\circ} \mathrm{C}$. The colour was also evaluated after a further $48 \mathrm{~h}$ of storage at $4^{\circ} \mathrm{C}$ to show possible 'alterations' of colour during meat storage. 
Water-holding capacity (WHC). WHC was determined using three different methods:drip loss, as the weight loss of the meat sample used for colour determination, kept at $4^{\circ} \mathrm{C}$ for $48 \mathrm{~h}$ in a plastic container with a double bottom; cooking loss on the meat sample used for drip loss and then cooked on a metal tray in an oven at $180^{\circ} \mathrm{C}$ to an internal temperature of $75^{\circ} \mathrm{C}$; and filter paper press method (Grau and Hamm, 1957), expressed as the ratio M/T, where $\mathrm{M}$ is the area $\left(\mathrm{cm}^{2}\right)$ of the meat and $\mathrm{T}$ is the total area $\left(\mathrm{cm}^{2}\right)$ : therefore a larger value indicates a higher WHC (Hofmann et al., 1982).

Shear force. Tenderness was evaluated as the shear force $(\mathrm{kg})$ using Warner-Bratzler Shear applied to an Instron 1011, on 1-inch $(2.54 \mathrm{~cm})$ diameter cylinders of raw meat and meat cooked on a metal tray in an oven at $180^{\circ} \mathrm{C}$ to an internal temperature of $75^{\circ} \mathrm{C}$ and not allowed to cool. For each sample four cylinders of about $2.5 \mathrm{~cm}$ length were taken parallel to muscular fibres and placed inside the WarnerBratzler to be sheared perpendicularly to the long axis of the muscle fibres.

\section{Statistical analysis}

The data was analysed against treatment by one-way analysis of variance (ANOVA), using an SPSS package (Statistical Packages for the Social Sciences, 1997) and post hoc analysis was performed by Tukey test to split groups with significant differences.

\section{Results and discussion}

Previous reports concerning the effects of dexamethasone on growth rate in cattle have provided conflicting evidence.

In our study the animals treated with oral dexamethasone obtained the lowest daily weight gain $(P<0.05)$ and the poorest FCR $(P<0.05)$, (Table $1)$. Hot dressing percentage, cold dressing percentage and shrinkage were not affected by the oral treatment (Table 2).

The i. m. injections of dexamethasone did not influence the overall performance.

Literature data about the effects of dexamethasone (DEX) on productive traits appears to be controversial and i. m. administration seems to be the preferred way.

Johnson and Silcox (1986) found that DEX decreased the average daily gains of yearling Angus bulls (in this study 30 Angus bulls received $20 \mathrm{mg}$ of DEX each). Renaville et al. (1993), conversely, found that the treatment with DEX (unspecified dosage) increased daily gains in Belgian Blue-White bulls.

Istasse et al. (1989) used two 14-month-old twin bulls of the Belgian Blue-White breed, one of which received 4 i. m. injections of DEX every 7 days (0.02 $\mathrm{mg}$ per $\mathrm{kg}$ body weight). Low doses of

\begin{tabular}{|c|c|c|c|c|c|c|}
\hline & \multicolumn{6}{|c|}{ Treatment } \\
\hline & \multicolumn{2}{|c|}{ Control } & \multicolumn{2}{|c|}{ Dexamethasone i.m. } & \multicolumn{2}{|c|}{ Oral dexamethasone } \\
\hline & Mean & s.e. & Mean & s.e. & Mean & s.e. \\
\hline Weight gain (kg) & $43 \cdot 5^{\mathrm{a}}$ & $6 \cdot 07$ & $40 \cdot 12^{\mathrm{a}}$ & $3 \cdot 87$ & $22^{\mathrm{b}}$ & 1.72 \\
\hline Daily weight gain ( $\mathrm{kg} /$ day) & $1 \cdot 21^{\mathrm{a}}$ & $0 \cdot 17$ & $1 \cdot 15^{\mathrm{a}}$ & $0 \cdot 11$ & $0 \cdot 63^{b}$ & $0 \cdot 05$ \\
\hline Food conversion ratet & $5 \cdot 86^{\mathrm{b}}$ & $1 \cdot 25$ & $5 \cdot 9^{b}$ & $1 \cdot 13$ & $9 \cdot 08^{\mathrm{a}}$ & $0 \cdot 87$ \\
\hline
\end{tabular}

a,b Letters split groups $(P<0 \cdot 05)$ according to Tukey test.

+ Dry weight of food consumed/weight gain.

Table 2 Effects of dexamethasone on carcass traits

\begin{tabular}{|c|c|c|c|c|c|c|}
\hline & \multicolumn{6}{|c|}{ Treatment } \\
\hline & \multicolumn{2}{|c|}{ Control } & \multicolumn{2}{|c|}{ Dexamethasone i.m. } & \multicolumn{2}{|c|}{ Oral dexamethasone } \\
\hline & Mean & s.e. & Mean & s.e. & Mean & s.e. \\
\hline Hot dressing proportion (g/kg) & 5913 & $7 \cdot 6$ & $577 \cdot 5$ & $6 \cdot 1$ & $569 \cdot 6$ & $8 \cdot 9$ \\
\hline Cold dressing proportion $(\mathrm{g} / \mathrm{kg})$ & $576 \cdot 7$ & $8 \cdot 2$ & $565 \cdot 5$ & $7 \cdot 7$ & $557 \cdot 9$ & 9.9 \\
\hline Shrinkage $(\mathrm{g} / \mathrm{kg})$ & $24 \cdot 8$ & $1 \cdot 8$ & $20 \cdot 8$ & $3 \cdot 9$ & $20 \cdot 5$ & $2 \cdot 8$ \\
\hline
\end{tabular}


Table 3 Chemical composition ( $\mathrm{g} / \mathrm{kg}$ fresh-matter basis)

\begin{tabular}{|c|c|c|c|c|c|c|}
\hline & \multicolumn{6}{|c|}{ Treatment } \\
\hline & \multicolumn{2}{|c|}{ Control } & \multicolumn{2}{|c|}{ Dexamethasone i.m. } & \multicolumn{2}{|c|}{ Oral dexamethasone } \\
\hline & Mean & s.e. & Mean & s.e. & Mean & s.e. \\
\hline Dry matter & $240 \cdot 5$ & $2 \cdot 6$ & $234 \cdot 2$ & $4 \cdot 0$ & $231 \cdot 6$ & $4 \cdot 8$ \\
\hline Crude protein & $214 \cdot 1$ & $2 \cdot 0$ & $212 \cdot 0$ & 3.8 & $209 \cdot 2$ & $2 \cdot 8$ \\
\hline Ether extract & $11 \cdot 0$ & $2 \cdot 2$ & 8.9 & $3 \cdot 1$ & $7 \cdot 0$ & $2 \cdot 3$ \\
\hline Ash & $12 \cdot 0$ & $11 \cdot 6$ & $11 \cdot 1$ & $36 \cdot 9$ & $12 \cdot 0$ & $40 \cdot 5$ \\
\hline
\end{tabular}

$\mathrm{DM}=$ dry matter, $\mathrm{CP}=$ crude protein, $\mathrm{EE}=$ ether extract.

glucocorticoids resulted in improved food intake, increased live-weight gain, reduced FCR, reduced nitrogen retention. The weight of the warm and cold carcass was greater in the DEX treated bull than in the control animal.

In an experiment of Corah et al. (1995) six steers with an implant containing $100 \mathrm{mg}$ of DEX had a greater subcutaneous fat thickness at the 12th rib and a larger longissimus muscle area than did the control steers. In addition, because of their greater external fatness and increased muscularity, treated steers had a higher dressing percentage (1.9 percentage points higher).
McCurdy et al. (2002) reported that intramuscular injections of $0.1 \mathrm{mg}$ DEX per $\mathrm{kg}$ body weight appeared to increase food efficiency.

Chemical composition of muscle was not affected by the drug treatments (Table 3); Istasse et al. (1989) conversely found that there was a reduction in DM and $\mathrm{CP}$ content and an increase in the EE content. According to McCurdy et al. (2002) the stimulation of intramuscular adipose tissue by DEX administration may be able to increase marbling at a particular time or stage of tissue development.

The results for meat quality (Table 4 ) show that $\mathrm{pH}$ was not influenced by treatment. Colour

Table 4 Meat quality traits after 6 days of storage at $4^{\circ} \mathrm{C}$ in vacuum packs

\begin{tabular}{|c|c|c|c|c|c|c|}
\hline & \multicolumn{6}{|c|}{ Treatment } \\
\hline & \multicolumn{2}{|c|}{ Control } & \multicolumn{2}{|c|}{ Dexamethasone i.m. } & \multicolumn{2}{|c|}{ Oral dexamethasone } \\
\hline & Mean & s.e. & Mean & s.e. & Mean & s.e. \\
\hline $\mathrm{pH}$ & $5 \cdot 41$ & $0 \cdot 01$ & $5 \cdot 38$ & 0.03 & $5 \cdot 37$ & $0 \cdot 02$ \\
\hline \multicolumn{7}{|l|}{ Colour } \\
\hline $\mathrm{L}^{*}$ & $58 \cdot 43^{b}$ & $1 \cdot 16$ & $60 \cdot 87^{a b}$ & $1 \cdot 12$ & $63 \cdot 57^{a}$ & $0 \cdot 85$ \\
\hline$C^{*}$ & $10 \cdot 65$ & $0 \cdot 87$ & $13 \cdot 34$ & 0.96 & $13 \cdot 35$ & $0 \cdot 53$ \\
\hline $\mathrm{H}^{*}$ & 39.59 & 1.74 & $40 \cdot 48$ & 0.53 & $42 \cdot 82$ & $0 \cdot 68$ \\
\hline \multicolumn{7}{|c|}{ Colour after a further $48 \mathrm{~h}$} \\
\hline $\mathrm{L}^{*}$ & $59 \cdot 58$ & 1.24 & $61 \cdot 46$ & 0.99 & $63 \cdot 57$ & $1 \cdot 27$ \\
\hline$C^{*}$ & $12 \cdot 65$ & 0.93 & $14 \cdot 85$ & $1 \cdot 13$ & $14 \cdot 20$ & 0.56 \\
\hline $\mathrm{H}^{*}$ & $42 \cdot 13$ & 1.67 & $42 \cdot 41$ & 0.80 & $43 \cdot 90$ & $1 \cdot 19$ \\
\hline \multicolumn{7}{|l|}{ Shear force } \\
\hline Raw meat (kg) & $7 \cdot 84$ & $0 \cdot 43$ & $7 \cdot 09$ & 0.54 & $6 \cdot 74$ & $0 \cdot 45$ \\
\hline Cooked meat (kg) & $6 \cdot 33^{\mathrm{a}}$ & $0 \cdot 27$ & $5 \cdot 00^{\mathrm{b}}$ & $0 \cdot 43$ & $4 \cdot 67$ & $0 \cdot 43$ \\
\hline \multicolumn{7}{|l|}{ Water-holding capacity } \\
\hline $\mathrm{M} / \mathrm{T}+$ & $0 \cdot 42^{\mathrm{a}}$ & $0 \cdot 01$ & $0 \cdot 37^{\mathrm{b}}$ & 0.02 & $0 \cdot 42^{\mathrm{a}}$ & $0 \cdot 01$ \\
\hline Drip loss (g/kg) & $2 \cdot 67$ & $0 \cdot 32$ & $3 \cdot 21$ & $0 \cdot 50$ & $2 \cdot 69$ & $0 \cdot 22$ \\
\hline Cooking loss (g/kg) & $27 \cdot 81$ & $3 \cdot 10$ & 29.98 & 1.98 & $25 \cdot 63$ & $2 \cdot 48$ \\
\hline
\end{tabular}

a,b Letters split groups $(P<0.05)$ according to Tukey test.

$+\mathrm{M}=$ area $\left(\mathrm{cm}^{2}\right)$ of the meat, $\mathrm{T}=$ the total area $\left(\mathrm{cm}^{2}\right)$, in the filter paper press method. 
characteristics were affected by DEX: the meat of calves treated with oral dexamethasone was significantly lighter $\left(\mathrm{L}^{*}\right)(P<0.05)$ and tended to be paler $\left(\mathrm{H}^{*}\right)$, while i.m. treatment induced intermediate characteristics. The measure of meat colour after a further $48 \mathrm{~h}$ of storage at $4^{\circ} \mathrm{C}$, shows that dexamethasone treatments have no effect on colour stability.

The calves' meat as a whole was very tender, as shown by the low shear force value before and after the cooking process; cooked meat of oral and i. m. dexamethasone treated animals was significantly more tender than the control $(P<0 \cdot 05)$, due to the effect of dexamethasone on this quality trait, in contrast to the findings of Istasse et al. (1989).

The i. m. dexamethasone treatment reduced waterholding capacity, as shown by the significantly lower M/T ratio and the higher, although not statistically significant, values of drip loss and cooking loss; these results are not in agreement with Istasse et al. (1989) who found a higher water-holding capacity as indicated by a reduction of drip and cooking losses in the animals treated with i. m. dexamethasone. The oral treatment induced no alteration in water-holding capacity.

\section{Conclusion}

Dexamethasone and other corticosteroids are frequently used as illegal growth promoters in livestock production (Courtheyn, 2002). Nevertheless the literature data concerning the effects of DEX on the growth rate in cattle has provided conflicting evidence. In our study, the use of dexamethasone at low dosage, both orally and intramuscularly, was found to have no positive effect on performance but it positively influenced meat tenderness and colour.

Otherwise the improvement of the meat quality traits could alternatively be achieved by appropriate housing, management and feeding techniques that also have an important influence on animal welfare : these aspects have to be better understood by some breeders in order to avoid the use of illegal growth promoters.

\section{Acknowledgements}

Study supported by 'Regione Piemonte' grant (Italy) : regional project 'Residues national project and the improvement of related controls action'. The authors wish to thank Mrs Chiara Bianchi for her capable technical support.

\section{References}

Association of Official Analytical Chemists. 1990. Official methods of analysis. Association of Official Analytical Chemists, Inc., Arlington, VA.
Biolatti, B., Rosmini, R., Cravero, C., Angeletti, R., Bollo, E. and Del Piero, F. 1999. Genital and accessory reproductive organs, mammary gland and thymus changes following illegal anabolic treatment in veal calves. Proceedings of the 17th meeting of the European Society of Veterinary Pathology, Nantes, p. 175.

Biolatti, B., Valpreda, M., Barbarino, G., Costadura, G., Morero, P., Gatto, S., Pellegrini, S., Cavallo, M., Zancanaro, G., Sereno, A. and Bellonio, A. 2002. Anabolic target organs pathology in cattle slaughtered in Piemonte region (Italy). Proceedings of the 20th meeting of the European Society of Veterinary Pathology, - Grugliasco (TO), p 58.

Corah, T. J., Tatum, J. D., Morgan, J. B., Mortimer, R. G. and Smith, G. C. 1995. Effects of a dexamethasone implant on deposition of intramuscular fat in genetically identical cattle Journal of Animal Science 73: 3310-3316.

Courtheyn, D., Le Bizec, B., Brambilla, G., De Brabander, H. F., Cobbaert, E. and Wiele M. van de. 2002. Recent developments in the use and abuse of growth promoters. Analytica Chimica Acta 473: 71-82.

Courtheyn, D., Verheye, N., Bakeroot, V., Dal, V., Schilt, R., Hooijerink, H., Bennekom, E. O., Haasnoot, W., Stouten, P. and Huf, F. A. 1993. Detection of corticosteroids in animal feed and premixes: a new category of growth promoters. Proceedings of EuroResidue II 1, p. 262.

European Commission. 1997. Decision 97/182/EC. Web site: http: //europa. eu. int/comm7foodfs/aw/aw_refer ences_en. html

Grau, R. and Hamm, R. 1957. [On the water holding capacity of mammal muscles. II. On the determination of the water holding of muscles]. Zeitschrift für LebensmittelUntersuchung und-Forschung 105: 446-460.

Hofmann, K., Hamm, R. and Bluchel, E. 1982. New information on the determination of water binding in meat by the filter paper press method. Fleischwirtsch 62: 87-94.

Istasse, L., Haan, V. de, Eenaeme, C. van, Buts, B., Baldwin, P., Gielen, M., Demeyer, D. and Bienfait, J. M. 1989. Effects of dexamethasone injections on performances in a pair of monozygotic cattle twins. Journal of Animal Physiology, Section A: Animal Nutrition 62: 150-158.

Istat. 2001. Report 2001 [National Institute of Statistics] at www. istat. it

Johnson, B. H. and Silcox, R. W. 1986. The utilization of dexamethasone for feedlot bulls: a preliminary investigation. Animal science report of North Carolina State University, Raleigh.

McCurdy, M., Buskirk, D. D., Grant, A. and Cowley, J. 2002. Influence of supplemental sunflower oil and dexamethasone therapy on performance and adipose tissue development in early weaned beef steers. Michigan State University beef cattle, sheep and forage systems research and demonstration report.

Renaville, R., Massart, S., Devolder, A., Sneyers, M., Burney, A. and Portetelle, D. 1993. Effects of dexamethasone treatment on growth, sexual axis and hormonal status in finishing bulls. Journal of Animal Science 71: (suppl. 1) 232 (abstr.).

Renerre, M. 1982. [Meat colour and its measurement. ] Bulletin Technique, C. R. Z. V. Theix. I. N. R. A. 47: 47-54. 
Statistical Packages for the Social Sciences. 1997. Base 7.5 for Windows, user's guide. SPSS Inc., Chicago, Illinois, USA.

Ungemach, F. R. 1997. [Pharmacological influence of inflammation.] In [Companion and large animal pharmacotherapy, third edition] (ed. W. Löscher, F. R.
Ungemach, R. Kroker and P. Verlag), pp. 485. Blackwell Wissenschafts, Germany.

(Received 3 December 2003-Accepted 18 February 2004) 